\title{
INFECTION OF CYCLOSPORA CAYETANENSIS IN CHILDREN UNDER 15 YEARS OF AGE IN KATHMANDU VALLEY
}

\author{
Rabin Paudyal*, Sarmila Tandukar*, Ojaswee Sherchand***, \\ Jyoti Amatya** and J eevan B. Sherchand* \\ *Public Health Research Laboratory, Department of Medical Microbiology, Tribhuvan University Teaching \\ Hospital, Maharajgunj, Kathmandu, Nepal. \\ **Department of Microbiology, Kathmandu College of Science and Technology, Kalimati, Kathmandu, Nepal. \\ ***Dirgh-J eevan Health Care and Research Centre, Tripureswar, Kathmandu, Nepal.
}

\begin{abstract}
Cyclospora cayetanensis is a rapidly emerging pathogen in developing countries like Nepal. It causes persistent diarrhea in children and in immunocompromised individuals. The study was carried out in children less than 15 years of age in Kathmandu Valley. A total of 302 stool samples were collected from different Sukumbasi (Slum children) areas of Kathmandu Valley. The samples were observed microscopically using normal saline and potassium dichromate preparation and the test was further confirmed by Sheather's sucrose flotation and Kinoyoun's modified acid fast staining technique. Out of the total sample processed C. cayetanensis oocysts were found in 24 (7.94 \%) cases. The oocyst were distributed more in children of age group 3-6 years which constituted $5.49 \%$ of the total cases $(\div 2=69.15 \mathrm{p}: 0.001)$ and distributed more in months of June (8) and July (8) $(\div 2=9.042 \mathrm{p}$ : 0.250) whereas abdominal pain was the most common symptoms in infected children. These findings indicate that $C$. cayetanensis is rapidly emerging enteropathogen in children. So, active surveillance should be continued among diarrhea patients to look for different $C$. cayetanensis infection and to define the shifting patterns in the seasonal variations of this parasite.
\end{abstract}

Key words: Cyclospora cayetanensis; Diarrhea; Children; Faecal specimen.

\section{INTRODUCTION:}

C.cayetanensis is a coccodian parasite that causes prolonged diarrhea in human worldwide (Ortega, 1993). First reports of C. cayetanensis were made in Papua New Guinea (Ashford, 1973). More recent reports are from North, Central and South America, The Indian Subcontinent, South East Asia and Australia (Sterling et al., 1997). The high endemic areas are Peru (Ortega, 1997), Haiti (Pape et al., 1994) and Nepal (Sherchand and Cross 2002) Children acquire the infection by ingesting the sporulated oocyst. Water has been considered an important agent in outbreaks in Nepal (Rabold et al., 1994; Sherchand and Cross, 1997). Leafy vegetables have also been reported as major source of infection (Ortega et al., 1997) and Nepal (Sherchand et al., 1997). The oocyst of Cyclospora measures about $8 \mu \mathrm{m}$ to $10 \mu \mathrm{m}$ in diameter. The life cycle completes in single host. The life cycle starts with the ingestion of sporulated oocyst which consists of 2 sporocysts and each enclosing 2 sporozoites. Inside the gut the sporozoites penetrate the epithelial cells and hence progresses to schizogony and gametogony. Sporogony and sporulation occur exogenously (DOB 2000) Individuals infected with Cyclospora may experience prolonged watery diarrhea, abdominal cramping, Weight loss, anorexia, myalgia and occasionally vomiting. The incubation period may vary from 7-14 days on the basis of numbers of sporulated oocyst ingested. The parasite inflames the small intestine causing vilous atropy and crypt hyperplasia, Succesful treatment has been achieved by cotrimoxazole (160mg trimethoprim, 800 mg sulphamethaoxazole). A number of studies have been carried out in Nepal among expatriates and Tourists (Shim et al.,) but only few studies have been carried out in the local people. So this study was carried out to find out the prevalence of $C$. cayetanensis in children of Kathmandu Valley. The main aim of this study was to establish $C$. cayetanensis as a rapidly emerging pathogen in children. Since the biology and transmission issue of this parasite is not solved completely, further investigations on this parasite must be raised.

\section{MATERIALS AND METHODS:}

The study was conducted between April to November 2009 in Tribhuvan University Teaching Hospital, Public Health Research Laboratory, Maharajgunj and Dirgh Jeevan Health

Author for Correspondence: J.B. Sherchand, Department of Medical Microbiology and PHRL, Tribhuvan University Teaching Hospital Maharajgunj, Kathamandu, Nepal. 
Care and Research Centre, Tripureswar, Kathmandu Nepal. A total of 302 samples were collected from different slum children of Kathmandu valley. Of them including Maharajgunj slum (113), Thapathali slum (66), Tripureswar slum (51), Koteshor slum (25) and Balkhu Slum (11). Data on predisposing factors were collected along with written consent from the respective children's parents. Stool sample was collected in clean wide mouth container. The $2.5 \%$ potassium dichromate solution was used as a transportation as well as preservation of the specimen. The collected samples were observed in normal saline by direct microscopy. Sheather's sucrose flotation concentration technique was used further for detection of oocyst and then confirmed by Kinoyun's modified acid fast staining technique.

\section{RESULTS:}

Out of the total 302 stool specimen 24 (7.94 \%) were found to be positive for Cyclospora cayetanensis infection. Of the 24 positive cases 18 (75\%) were male and 6 (25\%) were female. Agewise prevalence of Cyclospora cayetanensis showed that the infection was more prevalent in children within age group 3-6 years of age. Regarding Monthwise infection (Table 2) significant infection was found in month of July (19.04\%) and in month of June (16.66 \%). No infection by Cyclospora cayetanensis was detected in the month of September, October and November. As regards to sitewise prevalence of Cyclospora infection, there was no significant presence of Cyclospora cayetanensis on sitewise basis.

Co infection of Cyclospora with other intestinal parasites: Out of the 24 positive cases, 10 (41.66\%) showed co infection with Giardia lamblia. 4 (16.66\%) showed co infection with Entamoeba histolytica 4 (16.66\%) showed co infection with Blastocystis hominis and 6 were detected without any co infection.

Table 1: Gender wise distribution of C. cayetanensis

\begin{tabular}{|c|c|c|c|}
\hline Age group in years & Male & Female & Total parasite positive cases \\
\hline $0-3$ & 98 & 65 & 4 \\
\hline $3-6$ & 45 & 25 & 5 \\
\hline $6-9$ & 18 & 15 & 2 \\
\hline $9-12$ & 14 & 6 & 2 \\
\hline $12-15$ & 9 & 7 & 24 \\
\hline Total & 178 & 124 & 5 \\
\hline
\end{tabular}

Age wise $\div 2=69.15$ p: 0.001 ( Significant)

Gender wise $\div 2=1.144$ p: 0.285 (Not Significant)

Table 2: Month wise distribution of C. cayetanensis

\begin{tabular}{|c|c|c|c|c|}
\hline \multirow{2}{*}{ Months } & \multirow{2}{*}{ No of processed sample } & \multicolumn{2}{|c|}{ Positive } & \multirow{2}{*}{ Total } \\
\cline { 3 - 4 } & & Male & Female & $6(11.53 \%)$ \\
\hline April & 21 & 0 & 0 & $8(16.66 \%)$ \\
\hline May & 52 & 4 & 2 & $8(19.04 \%)$ \\
\hline June & 48 & 6 & 2 & $2(3.92 \%)$ \\
\hline July & 42 & 6 & 2 & 0 \\
\hline August & 51 & 0 & 0 & 0 \\
\hline September & 31 & 0 & 0 & 0 \\
\hline October & 30 & 0 & 0 & 0 \\
\hline November & 27 & 18 & 6 & 24 \\
\hline Total & 302 & & & 0 \\
\hline
\end{tabular}

Month wise $\div 2=16.042$ p: 0.0250 (Significant)

Table 3: Site wise distribution of C. cayetanensis in different Sukumbasi areas.

\begin{tabular}{|c|c|c|c|c|}
\hline Site of Collection & Total processed sample & Male & Female & Total \\
\hline Maharajgunj & 113 & 6 & 2 & 8 \\
\hline Thapathali & 66 & 4 & 2 & 6 \\
\hline Tripureshor & 51 & 4 & 2 & 6 \\
\hline Koteshor & 25 & 4 & 0 & 4 \\
\hline Balkhu & 11 & 0 & 0 & 0 \\
\hline Total & 302 & 18 & 6 & 24 \\
\hline
\end{tabular}

Site wise $\div 2=3.561$ p: 0.469 (Not Significant)

Table 4: Frequency distribution of $C$. caytenensis based on education of parent

\begin{tabular}{|l|c|c|c|}
\hline \multicolumn{1}{|c|}{ Educational level } & Total processed sample & Cyclospora Positive & Percentage \\
\hline Illiterate & 146 & 14 & $58.33 \%$ \\
\hline Under S.L.C & 109 & 8 & $33.33 \%$ \\
\hline S.L.C and above & 47 & 2 & $8.33 \%$ \\
\hline
\end{tabular}

Based on education of parent $\div 2=0.17$ p: 0.68 (Not significant) 
Figure 1: Frequency distribution of C. cayetanensis based on treatment of Water

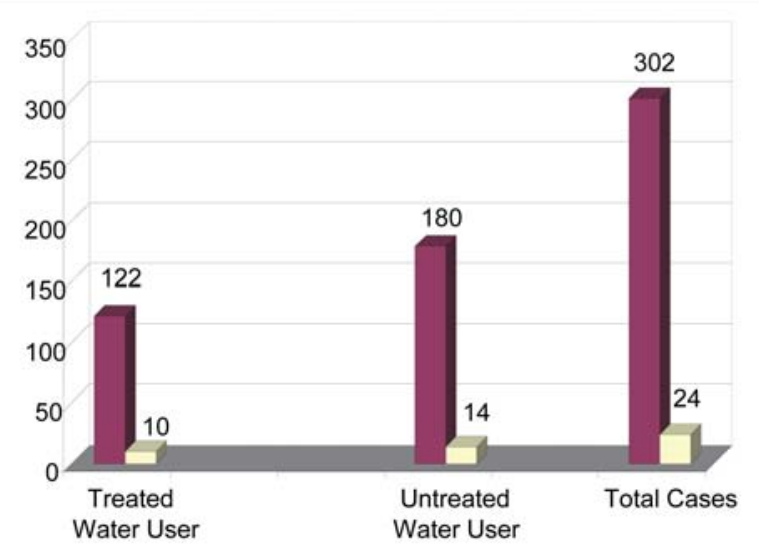

Based on treatment of water $\div 2=0.082$ p: 0.774 (Not significant)

\section{DISCUSSION:}

Cyclospora cayetanensis is a rapidly emerging pathogen in developing country like Nepal. The study showed that the infection was higher in children less than 10 years of age. Similiar results were obtained by Caryn et al., and Sherchand and Cross (2001). Sexwise prevalence of C.cayetanensis showed that there was no significant association between age and presence of infection. Similiar report is shown by Amim et al., (1998). In the present study the infection was found to occur in children of slums. .Though the sample size was small but the presence of parasite was significant. This may be attributed to low level of sanitation and maintenance of hygiene in children of slums. The present study also showed marked seasonal variation of Cyclospora infection with a high incidence of infection during warm rainy season i.e at July. This agrees with the findings by Hoge et al., (1993). But this finding doesnot agree with earlier findings by Ortega et al., (1997) in which peak infection occurred in warm dry seasons. Cyclospora cayetanensis was found in coinfection with other enteroparasites. Out of the 24 positive cases, Out of the 24 positive cases, 10 (41.66\%) showed co infection with Giardia lamblia. 4 (16.66\%) showed co infection with Entamoeba histolytica 4 (16.66\%) showed co infection with Blastocystis hominis and 6 were detected without any co infection Amin found the pathogens like E. histolytica and G. lamblia reduces the immunity which may result in new infection. Though actual biology of transmission of $C$. cayetanensis is not known. But it has been reported to be transmitted through water, soil (Ortega et al., 1997). Though oocysts of Cyclospora cayetanensis have been found in chicken, dogs and rats the possibility of human infection by zoonosis is not clear (Sherchand and Cross 2002; Garcia et al., 1996; Yai et al., 1997; Eberhard et al., 1999).

\section{CONCLUSION:}

This study concludes that Cyclospora cayetanensis is a rapidly emerging pathogen as a causative agent of diarrhea in children. Children under 10 years of age were found more susceptible for the infection. The parasite found more active in dry rainy season. Contamination of water sources and usage of such water source leads for further making of suitable environment for this parasite. Further studies including all age groups might help to understand the actual transmission, pathogenicity and prevention of Cyclospora infection.

In addition, we need to develop quick, inexpensive, reliable molecular and diagnostic tools and to identify alternative efficacious agents for therapy as well as prophylaxis.

\section{ACKNOWLEDGEMENT:}

The authors are thankful to Dr. Dirgh Singh Bam, Mr. Mekh Bahadur Pulami, Dr. Jatan B. Sherchan of Dirgh Jeevan Health care and Research centre, Tripureswar and all staffs and members of Public Health Research Laboratory, Department of Microbiology, Kathmandu College of Science and Technology for their support and cooperation.

\section{REFERENCES:}

Amin OM. 1998. Seasonal Prevalence and host relationships of Cyclospora cayetanensis in North American during 1996. Par. Int. 47: 53-58.

Ashford RW. 1973. Occurrence of an Undescribed Coccidian in Man in Papua New Guinea. Am. Trop Med Parasitol. 73, 497- 500.

Caryn, B., Hernanadez, B., Lopez, MB., Arrowood, MJ., Mejia Made, Merida, AM de, Hightower, AW., Venezel, L., Herwaldt, BL. and Klein, RE. (1999). Epidemiologic Studies of Cyclospora cayetanensis in Guatemala. Emerg Infect Dis. 5, 766-773.

Connor, BA. Shlim, DR. 1995. Food borne transmission of Cyclospora. Lancet. 2: 346:1634.

Cyclospora and Cryptosporidium in Florida and New York City. 1995. MMWR. 46: 354-358.

DOB: Cyclospora cayetanensis. Update: Division of Biology, Kansas State University, Manhattan, KS 2000.

Eberhard, ML., Eva, KN., Amanda, RF., Thomas, GS., Alexandre, J. Da silva and Patrick, JL. 1999. Cyclospora cayetanensis in Haiti: A Common Occurrence in the Absence of Watery Diarrhoea. Am J Trop Med Hyg . 60: 584-586.

Ford, P. and Duszynski, DW. 1988. Coccidian Parasites from Insectivores: VI Six New species from the Eastern Mole, Scalopus aquaticus. J Protozool. 35: 223-226.

Garcia-Lopez, HL., Rodriguez Tovar, LE. 1996. Identification of Cyclospora in Poultry. Emerg Infect Dis. 2: 356-357.

Hoge, CW., Echeverria, P., Rajah, R., Jacobs, J., Malthouse, S. haptman E, Jimenez, LM., Shlim, DR. 1995. Prevalence of Cyclospora species and Other Enteric Pathogens among Children less than 5 years of Age in Nepal. J of Clin Microb. 33: 3058-3060.

Hoge, CW., Shlim, DR., Rajah, R., Triplett, J., Shear, M., Robold, JG. and Echeverria, P. 1993. Epidemiology of Diarrhoeal illness Associated with Coccidian-like organisms among Travellers and Foreign Residents in Nepal. Lancet. 341: 1175-1179.

Ortega, YR., Sterling, CR., Gilman, RH., Cama, VA., Diaz, F. 1993. Cyclospora species: A New Protozoan Pathogen of Human. $N$ Engl J Med. 328: 1308-1312.

Ortega, YR., Nagle, R., Gilman, RH., Watanabe, J., Miyagui, J., Quispe, H. 1997. Pathological and Clinical Parasite Life Cycle Stages. $J$ Infect Dis. 176: 1584-1589. 
Ortega, YR., Rosas, CR., Gilman, RH., Miler, NJ., Cabrera, L., Taquiri, C., Sterling, CR. 1997. Isolation of Cryptosporidium parvum and Cyclospora cayetanensis from vegetables collected from Markets of an Endemic Region in Peru. AM J Trop Med Hyg. 57: 683-686

Pape, JW., Verdier, RI., Boney, M., Boney, J. and Johnson, WD. 1994. Cyclospora infection in Adults with HIV: Clinical Manifestations, Treatment and Prophylaxis. Ann Intern Med. 121: 654-657.

Pritchett, RG., Radke, C., Moore, V., Busenichner, FK. 1997. Outbreak of Cyclosporiasis, Northern Virginia-Washington: DC-Baltimore, Maryland. Metropolitan Area. 1997. MMWR. 46: 689-691.

Rabold, JG., Hoge, CW., Shlim, DR., Kefford, C., Rajah, R., Echeverria, P. 1994. Cyclospora outbreak Associated with Chlorinated Drinking Water. Lancet. 344: 1360-1361.

Sadak, HAH. and Malak, AZ. 2001. Experiential Studies on Cyclosporiasis. J Egypt Soc Parasitol. 31: 65-77.

Sherchand, JB. and Cross, JH. 2002. Studies on Cyclospora cayetanensis Infection in Nepal. The Tenth International Congress of Parasitology. 4-9: 71-88.

Sherchand, JB., Cross, JH., Jimba, M., Sherchand, S. and Shrestha, MP. 1999. Study of Cyclospora cayetanensis in Health Care Facilities, Sewage Water and Green Leafy Vegetables in Nepal. Southeast Asian J Trop Med Public Health. 30: 58-63.

Sherchand, JB., Ohara, H., Sherchand, S., Cross, JH., Shrestha, MP. 1997. Intestinal Parasitic Infection in Rural Areas of Southern
Nepal. J Inst Med. 19: 115-121.

Sherchand, JB. and Cross, JH. 2001. Emerging Pathogen Cyclospora cayetanensis Infection in Nepal. South east Asian J Trop Med Public Health. 32: 143-150.

Sherchand, JB. and Cross, JH. 2004. Cyclospora cayetanensis in Nepal: A study of Microbiological and Epidemiological aspects. NHRC, 3: 1-8.

Shlim, DR., Cohen, MT., Eaton, M., Rajah, R., Long, EC., Unger, BL. 1991. An algae-like organism associated with an outbreak of prolonged diarrhea among foreigners in Nepal. Am J Trop Med Hyg. 45: 383-9.

Smith, HV., Paton, CA., Girdwood, RWA., Mtambo, MMA. 1996. Cyclospora in Non-human Primates. Vet Rec. 138: 528 abstract.

Soave, R., Dubey, JP., Ramos, LJ. and Tummings, M. 1986. A New Intestinal Pathogen. Clin Res. 34: 533 abstract.

Sterling, CR., Ortega, YR., Hartwig, EC., Pawlowiez, MB., Cook, MT., Miller, JR. 1997. Update: Outbreaks of Pseudo Infection with Cyclospora and Cryptosporidium Florida and New York City (1995). MMWR 46: 354-358.

Wurtz, R. 1994. Cyclospora: A Newly Identified Intestinal Pathogens of Human. Clin Infect Dis. 18: 620-623.

Yai, LE., Bauab, AR., Hirschfeld, MP., Oliver, ML. de, Damkaceno, JT. 1997. The First Two Cases of Cyclospora in Dogs, Sao Paulo Brazil. Rev Int Med Trop Sao Paulo. 39: 177-179. 